\title{
THE INSULIN-GLUCOSE TOLERANCE TEST IN PITUITARY GROWTH RETARDATION
}

\author{
BY \\ OLAV TRYGSTAD \\ From the Paediatric Research Institute, University Hospital, Rikhospitalet, Oslo, Norway
}

(RECEIVED FOR PUBLICATION JANUARY 14, 1965)

The differential diagnosis of growth retardation has become of great importance in the past few years, since human growth hormone (HGH) treatment has become available to patients with pituitary dwarfism. The diagnosis of low birthweight dwarfism (Black, 1961) is usually easy, but before puberty the differentiation of constitutionally retarded growth (Wilkins, 1957) from pituitary dwarfism may be very difficult. The insulin tolerance test has proved, in our experience, a useful supplement to other tests in the selection of patients for HGH treatment, despite the contrary conclusions of some other workers (Colombo, Richterich, Rossi, and Feinsmith, 1962). In this paper we give our experience with the insulinglucose test, comparing its usefulness with that of other tests of endocrine function.

\section{Material and Methods}

During the past two years the insulin tolerance test has been carried out on 22 patients between 6 and 19 years of age who were diagnosed as having pituitary growth retardation. Of these, 13 are now receiving continuous treatment with HGH; 9 have been treated for more than a year with good response, their height increments ranging from 7 to $13 \mathrm{~cm}$. during the first year of treatment.

During the same period insulin tolerance tests have also been carried out on 12 patients in whom the diagnosis of constitutional growth retardation has been made, and on 15 control patients without hormonal or metabolic disorders, and of the same age distribution.

The insulin tolerance tests were carried out after the patients had been in hospital for at least three days on a moderately high carbohydrate diet. Patients with pituitary failure are known to be hypersensitive to insulin, which often causes a considerable decrease in blood sugar, followed by a very slow return to normal levels. Even when adrenaline or glucagon are injected the blood sugar rises only slowly. The usual insulin tolerance test may, therefore, be hazardous in these patients. For a standardized test without reduction of the insulin dose when insulin hypersensitivity is suspected, we have preferred the less dangerous insulin-glucose tolerance test (Engel and Scott, 1950).
Crystalline glucagon-free insulin, $0 \cdot 1$ I.U./kg. body weight is given intravenously. The insulin is diluted $1: 10$ in saline. 30 minutes after the insulin injection or when the first significant symptoms of hypoglycaemia appear, whichever is the earlier, the child is given oral glucose $1.75 \mathrm{~g} . / \mathrm{kg}$. (in apple juice). Capillary blood for sugar determination was obtained in this series at $0,20,30,45$, $60,90,120,150$, and 210 minutes after the insulin injection, but as no significant differences between the groups were found after the administration of glucose, the test may be ended at 60 minutes. Blood sugar determinations were performed by the method of Hagedorn, Halström, and Jensen (1935).

During the first 30 minutes the child is observed closely for signs of hypoglycaemia: if these occur a blood specimen must be obtained and glucose given immediately, intravenously in severe cases. In our series of patients with pituitary dwarfism, we observed significant hypoglycaemic signs in one patient (A.S.); oral glucose was given at 25 minutes and the signs rapidly subsided.

The insulin-glucose tolerance test is less time consuming than the ordinary insulin tolerance test, where the child has to be observed closely for hypoglycaemic signs for at least an hour after insulin injection. Furthermore, with the ordinary dosage, severe hypoglycaemia often occurs in patients with pituitary hypofunction, so that the test may have to be performed more than once, after starting with one-third the usual dose.

\section{Results}

Table 1 shows the mean results of the insulinglucose tolerance tests in the groups described. Table 2 gives further details about the tests performed on the patients with pituitary dwarfism in whom the diagnosis had been proved by response to $\mathrm{HGH}$ treatment over a period of more than a year.

In the normal child the blood sugar drops to about $50 \%$ of the initial fasting value in 15 to 20 minutes (Colombo et al., 1962). A fall below $50 \%$ is usually said to indicate an abnormal insulin tolerance (Williams, 1962), but this is not in accord with our experience. Table 3 presents the numbers of patients in whom the test was 'abnormal' by this 
TABLE 1

RESULTS OF INSULIN-GLUCOSE TOLERANCE TESTS

\begin{tabular}{|c|c|c|c|c|c|c|c|c|c|c|c|c|}
\hline & \multirow[t]{2}{*}{ No. } & \multicolumn{9}{|c|}{$\begin{array}{l}\text { Blood Sugar Concentrations After (minutes) } \\
\text { Mean } \pm \text { SD }\end{array}$} & \multicolumn{2}{|c|}{$\begin{array}{l}\text { Maximum } \\
\text { Decrease }\end{array}$} \\
\hline & & 0 & 20 & 30 & 45 & 60 & 90 & 120 & 150 & 210 & $\%$ & SD \\
\hline $\begin{array}{l}\text { Controls . . } \\
\text { Constitutional dwarfism } \\
\text { Pituitary dwarfism, HGH }\end{array}$ & $\begin{array}{l}15 \\
12\end{array}$ & $\begin{array}{l}94 \pm 9 \\
92 \pm 16\end{array}$ & $\begin{array}{l}45 \pm 6 \\
41 \pm 11\end{array}$ & $\begin{array}{l}60 \pm 13 \\
55 \pm 13\end{array}$ & $\begin{array}{l}114 \\
102\end{array}$ & $\begin{array}{l}142 \\
131\end{array}$ & $\begin{array}{l}168 \\
157\end{array}$ & $\begin{array}{l}157 \\
147\end{array}$ & $\begin{array}{l}138 \\
117\end{array}$ & $\begin{array}{l}91 \\
91\end{array}$ & 52 & $\begin{array}{l} \pm 6 \cdot 5 \\
\pm 7 \cdot 5\end{array}$ \\
\hline $\begin{array}{l}\text { treated more than } 1 \text { year } \\
\text { Pituitary dwarfism ? }\end{array}$ & $\begin{array}{r}9 \\
13\end{array}$ & $\begin{array}{l}88 \pm 15 \\
93 \pm 15\end{array}$ & $\begin{array}{l}53 \pm 14 \\
55 \pm 14\end{array}$ & $\begin{array}{l}42 \pm 11 \\
45 \pm 12\end{array}$ & $\begin{array}{l}94 \\
97\end{array}$ & $\begin{array}{l}127 \\
120\end{array}$ & $\begin{array}{l}149 \\
153\end{array}$ & $\begin{array}{l}136 \\
155\end{array}$ & $\begin{array}{l}118 \\
146\end{array}$ & $\begin{array}{r}91 \\
111\end{array}$ & $\begin{array}{l}52 \\
53\end{array}$ & $\begin{array}{l} \pm 15.5 \\
\pm 9.5\end{array}$ \\
\hline
\end{tabular}

TABLE 2

RESULTS OF INSULIN-GLUCOSE TOLERANCE TESTS IN 9 PATIENTS SHOWING GOOD RESPONSE TO TREATMENT WITH HGH FOR MORE THAN A YEAR

\begin{tabular}{|c|c|c|c|c|c|c|c|c|c|c|c|c|c|}
\hline \multirow[b]{2}{*}{ Patient } & \multirow{2}{*}{$\begin{array}{l}\text { Age } \\
\text { (yr.) }\end{array}$} & \multicolumn{2}{|c|}{ Height Increment } & \multicolumn{9}{|c|}{ Blood Sugar Concentration After (minutes) } & \multirow{2}{*}{$\begin{array}{c}\text { Maximum } \\
\text { Decrease } \\
(\%)\end{array}$} \\
\hline & & $\begin{array}{c}\text { Before } \\
\text { Treatment } \\
\text { (cm./yr.) }\end{array}$ & $\begin{array}{c}\text { On } \\
\text { Treatment } \\
\text { (cm./mth.) }\end{array}$ & 0 & 20 & 30 & 45 & 60 & 90 & 120 & 150 & 210 & \\
\hline $\begin{array}{c}\text { A.S. } \\
\text { C.S. } \\
\text { A.S.F. } \\
\text { T.V. } \\
\text { T.H.S. } \\
\text { T.R.M. } \\
\text { R.E. } \\
\text { K.V. } \\
\text { O.L. }\end{array}$ & $\begin{array}{c}12 \frac{1}{2} \\
9 \frac{1}{2} \\
9 \\
16 \\
12 \frac{1}{2} \\
8 \frac{1}{2} \\
19 \\
6 \\
10\end{array}$ & $\begin{array}{c}9 / 5 \\
6 / 4 \frac{1}{2} \\
23 / 6 \\
25 / 9 \\
15 / 7 \frac{1}{2} \\
11 / 5 \frac{1}{2} \\
28 / 9 \frac{1}{2} \\
6 / 1 \frac{1}{2} \\
16 / 4\end{array}$ & $\begin{array}{r}24 / 36 \\
28 / 36 \\
16 / 27 \\
14 / 24 \\
11 / 24 \\
9 / 15 \\
9 / 13 \\
7 / 12 \\
7 / 12 \\
\end{array}$ & $\begin{array}{r}90 \\
115 \\
95 \\
78 \\
57 \\
76 \\
93 \\
97 \\
90\end{array}$ & $\begin{array}{l}48 \\
58 \\
44 \\
57 \\
47 \\
32 \\
72 \\
80 \\
41\end{array}$ & $\begin{array}{l}25^{*} \\
31 \\
38 \\
44 \\
42 \\
46 \\
47 \\
67 \\
39\end{array}$ & $\begin{array}{r}107 \\
94 \\
100 \\
86 \\
63 \\
72 \\
97 \\
107 \\
117\end{array}$ & $\begin{array}{r}136 \\
151 \\
140 \\
117 \\
115 \\
76 \\
127 \\
154 \\
123\end{array}$ & $\begin{array}{r}210 \\
155 \\
164 \\
130 \\
129 \\
72 \\
193 \\
125 \\
173\end{array}$ & $\begin{array}{r}154 \\
206 \\
125 \\
107 \\
132 \\
68 \\
171 \\
117 \\
140\end{array}$ & $\begin{array}{r}141 \\
131 \\
86 \\
101 \\
154 \\
105 \\
150 \\
82 \\
109\end{array}$ & $\begin{array}{r}106 \\
76 \\
94 \\
105 \\
80 \\
86 \\
101 \\
78 \\
97\end{array}$ & $\begin{array}{l}72 \\
73 \\
60 \\
44 \\
26 \\
58 \\
49 \\
31 \\
56\end{array}$ \\
\hline $\begin{array}{l}\text { Mean: } \\
\pm \text { SD }\end{array}$ & $11 \frac{1}{2}$ & $2 \cdot 65 / 1$ & $7 \frac{1}{2} / 12$ & $\begin{array}{c}88 \\
15 \cdot 2\end{array}$ & $\begin{array}{c}53 \\
14 \cdot 4\end{array}$ & $\begin{array}{c}42 \\
11 \cdot 1\end{array}$ & $\begin{array}{c}94 \\
16 \cdot 2\end{array}$ & $\begin{array}{c}127 \\
21 \cdot 9\end{array}$ & $\begin{array}{c}149 \\
37 \cdot 7\end{array}$ & $\begin{array}{c}136 \\
37 \cdot 0\end{array}$ & $\begin{array}{c}118 \\
25 \cdot 4\end{array}$ & $\begin{array}{c}91 \\
11 \cdot 5\end{array}$ & $\begin{array}{c}52 \\
15 \cdot 5\end{array}$ \\
\hline
\end{tabular}

* 25-minute blood sample (hypoglycaemic symptoms).

TABLE 3

MAGNITUDE OF BLOOD SUGAR DECREASE DURING INSULIN-GLUCOSE TOLERANCE TEST

\begin{tabular}{|c|c|c|c|}
\hline & & Blood Sugar & Decrease of \\
\hline & & $>\underset{(\text { No. })}{50 \%}$ & $\begin{array}{c}\quad 60 \% \\
\text { (No.). }\end{array}$ \\
\hline $\begin{array}{l}\text { Controls . } \\
\text { Constitutional dwarfism } \\
\text { Pituitary dwarfism, HGH } \\
\text { Pituitary dwarfism ? }\end{array}$ & $\begin{array}{l}\cdots \\
\cdots \\
\cdots\end{array}$ & $\begin{array}{l}9 / 15 \\
9 / 12 \\
5 / 9 \\
8 / 13\end{array}$ & $\begin{array}{l}2 / 15 \\
4 / 12 \\
2 / 9 \\
3 / 13\end{array}$ \\
\hline
\end{tabular}

criterion, showing that there was no difference between the groups: 6 patients in whom pituitary function was presumed to be normal showed a fall in blood sugar to below $40 \%$ of the initial fasting value.

During the first 20 minutes the decrease in blood sugar concentration after insulin injection seemed to be slightly greater in children with normal pituitary function than in those with hypopituitarism. The difference, however, is not statistically significant ( $\mathrm{p}$ between 0.05 and 0.025 ).

Table 4 and the Figure show the numbers of patients in each group where the lowest blood sugar value was recorded not in the 20 -minute but in the 30-minute sample. None of the controls or the patients with constitutional growth retardation had lower blood sugar values in the 30 -minute than in
TABLE 4

NUMBER OF CASES SHOWING DECREASE IN BLOOD SUGAR BETWEEN 20 AND 30 MINUTES

\begin{tabular}{lcccc|c}
\hline & & & & & No. \\
\hline Controls & & & & \\
Constitutional dwarfism & $\ldots$ & $\ldots$ & $\ldots$ & $\ldots$ & $0 / 15$ \\
Pituitary dwarfism, HGH treated & $\ldots$ & $\ldots$ & $\ldots$ & $0 / 12$ \\
Pituitary dwarfism ? & $\ldots$ & $\ldots$ & $\ldots$ & $\ldots$ & $8 / 9$ \\
& & & & & $12 / 13$ \\
\hline
\end{tabular}

the 20-minute sample. Two of the controls had the same concentration in the 20- and 30-minute samples, perhaps because the lowest level was reached between the two blood samples.

The change in blood sugar concentration between the 20- and the 30-minute sample is significantly different when compared with the controls in both groups of pituitary dwarfism $(p<0.001)$. The group with constitutional dwarfism shows no difference from the controls $(p=0 \cdot 9-0 \cdot 8)$.

Only two patients originally diagnosed as pituitary dwarfs had an increase in blood sugar from the 20-minute sample to the 30-minute sample. Both these patients had normal metyrapone tests, and there may be some doubt about the diagnosis. One of them (T.R.M.) was born with a grave foetal 


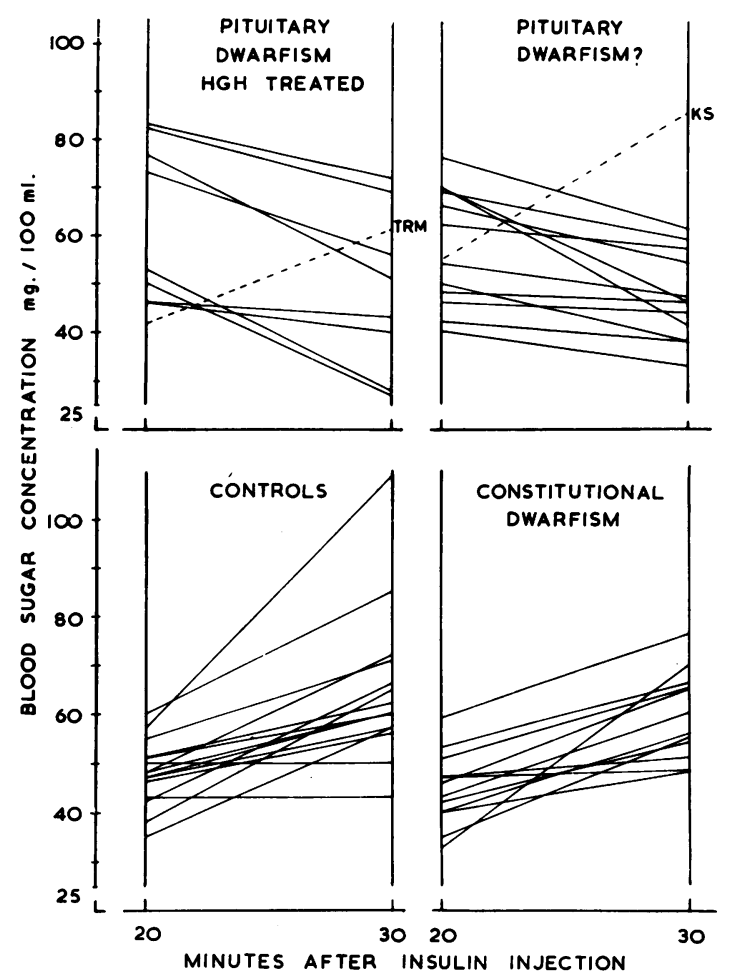

FIG.-Change in blood sugar concentration between 20 and 30 minutes after insulin injection in four groups of cases: proven pituitary dwarfism, unproven pituitary dwarfism, normal controls, and constitutional dwarfism. Broken lines indicate the two suspected pituitary dwarfs with normal insulin-glucose tolerance tests (see text). The blood-sugar concentrations are calculated after adjusting the fasting level to $100 \mathrm{mg} . / 100 \mathrm{ml}$.

asphyxia. He may possibly have a low birth weight dwarfism, because he and a younger sister had an intrauterine growth retardation, though he has grown $9 \mathrm{~cm}$. in 17 months on HGH treatment, having grown only $9 \mathrm{~cm}$. in the course of the previous 42 months. The other (K.S.) may also be suffering from constitutionally retarded growth and adolescent development, but because of his extreme shortness $(137 \mathrm{~cm}$. at 17 years) the effect of HGH was tried. However, the response has not been very striking after 8 months of treatment (height increment $4 \mathrm{~cm}$.).

We, therefore, regard the insulin-glucose tolerance test as abnormal when the blood sugar curve shows a continuous decrease until glucose is given.

\section{Discussion}

In childhood the differentiation of pituitary dwarfism from constitutional growth retardation is difficult, the diagnosis resting upon a number of features, none of which are pathognomonic.
The early diagnosis of pituitary dwarfism is important now that HGH treatment can be offered. In untreated cases our experience is the same as Kaplan's (1964), that the bone age of the pituitary dwarfed child increases with time more than does height age, so that the prognosis concerning the final height likely to be achieved with HGH therapy deteriorates with time.

The previous view (Daughaday, 1962) that pituitary growth retardation generally starts after the second year of life, is usually not familial, and is predominantly seen in boys, does not accord with our experience (Trygstad and Seip, 1964), and we regard these features as of little diagnostic value. Immunological methods for plasma HGH determinations do not as yet seem to be decisive in the diagnosis of pituitary dwarfism. Large and rapid variations in plasma $\mathbf{H G H}$ concentration occur during the day (Hunter, and Greenwood, 1964) and the values found in normal controls and in hypopituitarism overlap (Utiger, Parker, and Daughaday, 1962). Plasma HGH determinations after insulin hypoglycaemia may prove to be a more useful test.

The activity of the different pituitary hormones should be evaluated by the available tests. Though most pituitary dwarfs do not mature sexually, this is not always true (Antonin, 1961). The corticotrophin and thyrotrophin reserves may also be normal, so that the possibility of an isolated $\mathrm{HGH}$ deficiency must be considered.

Table 5 shows the main criteria on which we base the differential diagnosis between constitutional and pituitary growth retardation.

Table 6 shows the results in two other tests we have studied. The urinary excretion of 17-ketogenic steroids (17-KGS) has proved of no diagnostic value in our patients, all four groups having the same mean daily excretion of 17-KGS.

The metyrapone test, however, provides good evidence of the pituitary corticotrophin reserve. Metyrapone, $70-100 \mathrm{mg}$. $/ \mathrm{kg}$. body weight, is given orally in 6-10 doses during 24 hours. This substance blocks cortisol synthesis, and the blood concentration of its precursor, 11- $\beta$ hydroxycortisol (compound ' $S$ '), therefore increases. With a normal pituitary, therefore, there is increased corticotrophin secretion and increased compound ' $S$ ' formation. The increase in urinary excretion of compound ' $S$ ' (THS) after metyrapone is interpreted as normal when it exceeds $1 \mathrm{mg} . / 24 \mathrm{hr}$. and the increase of urinary $17-\mathrm{KGS}$ excretion exceeds $100 \%$.

The metyrapone test has been carried out in 18 patients provisionally diagnosed as pituitary dwarfism. Of these, 12 showed an abnormal and 6 a normal response. One of the latter had a craniopharyngioma 
with growth retardation during the past four years, and a height increment of only $2 \mathrm{~cm}$. during the past two years. In this patient the insulin-glucose tolerance test was abnormal, indicating a pituitary failure. Of the patients in Table 2 T.R.M. and R.E. had normal tests, A.S. had $300 \%$, and T.V. $100 \%$ increase in urinary $17-\mathrm{KGS}$ excretion.

None of our pituitary dwarfs have had hypoglycaemic episodes, and there are no significant differences in the fasting blood sugar levels between the groups (Table 1).

Hypoglycaemia induced by insulin is probably chiefly due to the increased peripheral uptake of glucose. The return of blood glucose concentration to normal levels may depend on several factors: (i) increased glucose release by the liver, (ii) decreased sensitivity of the peripheral tissue to insulin, e.g. caused by the increased growth hormone secretion evoked by the hypoglycaemia, (iii) an increase in the level of insulin inhibitors or antagonists, and (iv) gradual inactivation of the injected insulin.

The hypersensitivity to insulin in hypopituitarism and secondary adrenal insufficiency may be caused by changes in some or all of these factors, but we do not know which factor is most important.

Recently it has been demonstrated that insulininduced hypoglycaemia will produce an abrupt rise in the level of HGH in plasma (Hunter and Greenwood, 1964; Roth, Glick, Yalow, and Berson, 1964). Insulin and growth hormone seem to interact and behave like a new hormone that does not stimulate either glucose or free fatty acid uptake by the peripheral tissues (Zierler and Rabinowitz, 1963). Luft and Cerasi (1964) suggest that the biological activity of circulating insulin may be masked by increased amounts of an insulin inhibitor elicited by the growth hormone.

A number of years ago Young (1938) demonstrated that injections of anterior pituitary extracts in rabbits made the animals more resistant to the hypoglycaemic effect of insulin. Our own unpublished observations demonstrate that HGH treatment of pituitary dwarfs tends to restore the insulinglucose tolerance test to normal. The insulin tolerance test is generally considered to be a test of corticotrophin-adrenal reserve, but it may perhaps be a more specific test for the somatotrophic function of the pituitary.

\section{Summary}

The insulin-glucose tolerance test was performed on 22 patients diagnosed as pituitary dwarfism: in 9 of them the diagnosis had been confirmed by a growth response to human growth hormone. Only 2 patients had a normal test, and the diagnosis was doubtful in these.
TABLE 5

DIFFERENTIATION OF CONSTITUTIONAL FROM PITUITARY GROWTH RETARDATION

\begin{tabular}{|c|c|c|c|}
\hline Diagnostic signs & & $\begin{array}{c}\text { Constitu- } \\
\text { tional } \\
\text { Dwarfism }\end{array}$ & $\begin{array}{l}\text { Pituitary } \\
\text { Dwarfism }\end{array}$ \\
\hline $\begin{array}{l}\text { Familial occurrence } \\
\text { Growth retardation since birth } \\
\text { Growth velocity after third year } \\
\text { Puberty } \ldots \\
\text { Bone age retardation } \\
\text { Serum P, inorganic } \\
\text { Serum total cholesterol } \quad \ldots \\
\text { Serum protein-bound iodine } \\
\text { Metyrapone test ... } \\
\text { Insulin-glucose tolerance test }\end{array}$ & $\begin{array}{l}\cdots \\
\cdots \\
\cdots \\
\cdots \\
\cdots \\
\cdots \\
\cdots\end{array}$ & $\begin{array}{c}\text { Often } \\
\text { At times } \\
\text { 3-5 cm./yr. } \\
\text { Late } \\
\text { Moderate } \\
\text { Normal } \\
\text { Normal } \\
\text { Normal } \\
\text { Normal } \\
\text { Normal }\end{array}$ & $\begin{array}{c}\text { At times } \\
\text { At times } \\
1-4 \mathrm{~cm} . / \mathrm{yr} . \\
\text { Usually absent } \\
\text { Severe } \\
\text { Often low } \\
\text { Often high } \\
\text { Often low } \\
\text { Often abnormal } \\
\text { Often abnormal }\end{array}$ \\
\hline
\end{tabular}

TABLE 6

URINARY EXCRETION OF 17-KETOGENIC STEROIDS AND RESULTS OF METYRAPONE TEST

\begin{tabular}{|c|c|c|c|}
\hline & $\begin{array}{c}\text { Mean } \\
\text { Age** } \\
\text { (yr.) }\end{array}$ & $\begin{array}{c}\text { Mean } \\
\text { Daily } \\
\text { Excre- } \\
\text { tion of } \\
\text { 17-KGS } \\
\text { in Urine } \\
\text { (mg.) }\end{array}$ & $\begin{array}{c}\text { Ab- } \\
\text { normal } \\
\text { Mety- } \\
\text { rapone } \\
\text { Response }\end{array}$ \\
\hline Normals $\quad$. & $\begin{array}{r}10 \cdot 2 \\
(6-14)\end{array}$ & $2 \cdot 9$ & $0 / 9$ \\
\hline Constitutional growth retardation & $\begin{array}{c}(0-14) \\
9 \cdot 9 \\
(6-18)\end{array}$ & $3 \cdot 3$ & $0 / 12$ \\
\hline Pituitary dwarfism, HGH treated & $\begin{array}{l}11 \cdot 5 \\
(6-19)\end{array}$ & $3 \cdot 0$ & $7 / 9$ \\
\hline Pituitary dwarfism? & $\begin{array}{l}10 \cdot 6 \\
(6-18)\end{array}$ & $3 \cdot 0$ & $5 / 9$ \\
\hline
\end{tabular}

* The four groups were matched for age, except that all 9 children in the normal control group, being pre-pubertal, were less than 14 years.

The test was performed on 12 patients diagnosed as constitutional growth retardation and on 15 normal controls with the same age distribution as the pituitary dwarfs; all 27 had a normal test.

In interpreting the insulin-glucose test, the decrease in blood sugar between 20 and 30 minutes best differentiated the group of pituitary dwarfs.

In this study the insulin-glucose tolerance test proved a better diagnostic aid than the metyrapone test.

The author wishes to extend his thanks to Drs. T. M. Chalmers, Addenbrooke's Hospital, Cambridge; J. Jervell, Biochemical Institute, University of Oslo; and M. Seip, Paediatric Department, University Hospital, Oslo for advice.

\section{REFERENCES}

Antonin, J. M. F. (1961). Hypothalamo-hypophysärer Zwergwuchs mit spontaner Pubertät. Helv. paediat. Acta, 16, 267.

Black, J. (1961). Low birth weight dwarfism. Arch. Dis. Childh., 36, 633.

Colombo, J. P., Richterich, R., Rossi, E., and Feinsmith, B. (1962). Die diagnostische Bedeutung der Insulinbelastung. Ann. paediat. (Basel), 199, 110.

Daughaday, W. H. (1962). In Textbook of Endocrinology, by R. H. Williams, 3rd ed., pp. 51-53. W. B. Saunders, Philadelphia. Engel, F. L., and Scott, J. L. (1950). The insulin-glucose tolerance test. A modified procedure for the detection of hypoglycemia 
unresponsiveness in pituitary and adrenal insufficiency. J. clin. Invest., 29, 151.

Hagedorn, H. C., Halström, F., and Jensen, N. (1935). Hurtige metoder til bestemmelse av blodsukker ved kaliumferricyanid. Hospitalstidende, 78, 1193.

Hunter, W. M., and Greenwood, F. C. (1964). Studies on the secretion of human-pituitary-growth hormone. Brit. med. J., 1, 804.

Kaplan, S. A. (1964). Growth Disorders in Children and Adolescents, p. 69. Thomas, Springfield, Illinois.

Luft, R., and Cerasi, E. (1964). Effect of human growth hormone on insulin production in panhypopituitarism. Lancet, 2, 124.

Roth, J., Glick, S. M., Yalow, R. S., and Berson, S. A. (1964). The influence of blood glucose on the plasma concentration of growth hormone. Diabetes, 13, 355.

Trygstad, O., and Seip, M. (1964). Hereditary pituitary dwarfism treated with human growth hormone. Acta paediat. (Uppsala), 53, 527.

Utiger, R. D., Parker, M. L., and Daughaday, W. H. (1962). Studies on human growth hormone. I. A radioimmunoassay for human growth hormone. J. clin. Invest., 41, 254.

Wilkins, L. (1957). The Diagnosis and Treatment of Endocrine Disorders in Childhood and Adolescence. Blackwell Scientific Publications, Oxford.

Williams, R. H. (1962). Textbook of Endocrinology, 3rd ed., p. 621. W. B. Saunders, Philadelphia.

Young, F. G. (1938). The identity and mechanism of action of the glycotropic (anti-insulin) substance of the anterior pituitary gland. Biochem. J., 32, 1521.

Zierler, K. L., and Rabinowitz, D. (1963). Roles of insulin and growth hormone, based on studies of forearm metabolism in man. Medicine (Baltimore), 42, 385. 